\title{
A LEGALIDADE DA MORAL Considerações em torno da dupla moralidade da sociedade liberal
}

\author{
Hans-Georg Flickinger*
}

SÍNTESE - Em vez de questionar a legitimação da ação moral dentro do contexto da concepção moderna da moralidade comunicativa, segundo J. Habermas e K. O. Apel - 0 autor examina a argumentação hegeliana em seu livro Filosofia do Direito. A reconstrução desta visão revela que a idéia de moralidade, do ponto de vista moderno e liberal, deve ser reconhecida exclusivamente baseada na aceitação de estruturas legais e formais. Por isso, a qualidade moral da atividade humana é qualificada hoje como mero cumprimento de normas legais abstratas, sem qualquer referência a principios qualitativos de legitimação: "legalidade da moral" expressa essa experiência.

ABSTRACT - Instead of questioning the legitimation of moral action in the context of the modern conception of communicative morality (J. Habermas, K. O. Apel), the author reviews the hegelian argument, in his Philosophy of Right. His argument reveals that the idea of morality, from a modern and liberal point of view, must be recognized as exclusively based in the acceptance of formal legal structures. Therefore, the moral quality of human activity is qualified, today, as the mere fulfilling of abstract legal norms without reference to qualitative principles of legitimation: "legality of Moral" expresses that experience.

Ao logo da história do pensamento filosófico, uma das questões menos consensuais e, como sabemos hoje, nunca satisfatoriamente resolvidas é aquela que se refere à legitimação dos princípios fundamentadores do agir humano, i. é, da moralidade. Nem sempre dentro de uma mesma época conseguimos encontrar opiniōes claras no que tange aos critérios orientadores, considerados como moralmente inquestionáveis ou exemplares. Investigando, p. ex., a Idade Média - cuja ordem sociopolítica representou a forma secularizada do reino divino-cristão - não descobriríamos nenhuma conviç̧ão universalmente aceita quanto à base legitimadora da moralidade. Lembro apenas a luta de Abelardo, no século 12, por uma ética de convicção por sua vez incompativel com as dominantes correntes religiosas da época.

Frente a tais experiências históricas deveriamos partir do pressuposto da impossibilidade de apoiarmo-nos, de modo afirmativo, em princípios últimos de fundamentação do agir moral ou, o que é o mesmo, em idéias metafísicas para sua justificação. Aparentemente, resta apenas a tentativa de descobrir as concepções morais resultantes da respectiva configuração histórica da sociedade a fim de podermos identificar as normas morais nela vigentes. Em outras palavras, minhas considerações em torno da temática anunciada baseiam-se na suspeita segundo a qual teriamos que colocar em cheque a validade de princípios últimos de fundamentação da moral em favor da tentativa de descobrir a autoconsciência especifica que cada sociedade desenvolve em relação a suas convicções morais.

Professor de Filosofia da Universidade de Kassel, Alemanha, e da PUCRS.

\begin{tabular}{|l|l|l|l|l|l} 
VERITAS & Porto Alegre & v. 40 & $\mathrm{n}^{2} 157$ & Março 1995 & p.15-26
\end{tabular}


Tematizando os princípios morais da sociedade liberal, ou seja, a consciência determinadora do liberalismo moderno, não quero fugir de um segundo pressuposto, implícito na minha argumentação. Falo da tese do desencantamento do mundo moderno que, segundo o grande sociólogo Max Weber, é caracterizado pelo convívio necessário da ética do protestantismo com o desdobramento do capitalismo moderno. ${ }^{1}$ A base desta diagnose podemos esperar a compreensão tanto da concepção quanto do papel específico que se atribuem à legitimação moral do agir humano dentro dos limites da visão liberal.

Meu terceiro pressuposto a ser mencionado está ligado com a escolha do horizonte sistemático de meus raciocínios ou, mais precisamente, com a proximidade a um determinado autor filosófico por mim favorecido. Talvez exista, frente às diversas éticas disponíveis no panorama filosófico atual, a expectativa de eu tratar de uma destas como, p. ex., da ética comunicativa, defendida em primeira linha por J. Habermas e K. O. Apel. ${ }^{2}$ No entanto, não remeterei a estas concepções devido a um grave defeito não só inerente a esta última mas a todas as demais; defeito este que consiste na sua incapacidade de abranger tanto a esfera do agir comunicativo, quanto a da produção material como esferas complementares que constituem a vida sociopolítica como um todo. No meu entender, moralidade e eticidade só poderão dar orientação inequívoca ao agir humano se estiverem em condições de exigir sua validade em todos os níveis de relacionamento social. Por conseguinte, escolhi como base de argumentação o último esboço sistemático da moderna constituição liberal, capaz de tematizar o jogo recíproco entre os princípios que regem a socialização de nossa época junto a sua base material: a filosofia política de G. W. F. Hegel, ou seja, sua Filosofia do Direito. ${ }^{3}$ Espero poder legitimar esta minha opção ao longo da exposição que segue.

\section{1}

Para nossos fins seria exagerado querer reconstruir minuciosamente os argumentos do segundo grande capítulo da Filosofia do Direito que trata da questão do agir moral sob o título "moralidade subjetiva", já que nosso filósofo remete aí, em grande escala, a sua complexa exposição da idéia da liberdade na Ciência da Lógica e, mais especificamente, na "Lógica da reflexão". ${ }^{4}$ É-me, porém, necessário colocar rapidamente algumas observações referentes à passagem argumentativa que nos leva das figuras juridicas do assim chamado direito abstrato, i. é., da propriedade privada, do contrato civil e do crime, às questões ligadas aos critérios que deveriam definir o agir moral. ${ }^{5}$

1 Ver: Max Weber, Die protestantische Ethik und der Geist des Kapitalismus (A Ética do Protestantismo e o espirito do capitalismo), Introdução. 1904/1905.

2 Entre outros: Jürgen Habermas, Consciência moral e agir comunicativo, Ed. Tempo Brasileiro, Rio de Janeiro, 1989.

3 Cito, em seguida, a tradução de Orlando Vitorino, Guimarães Editores, Lisboa, $3^{\mathrm{a}}$ edição de Princípios da Filosofia do Direito, de G. W. F. Hegel. (cit.: FdD).

4 Trata-se do segundo livro da Ciência da Lógica, de G. W. F. Hegel (1812); infelizmente, falta até hoje uma tradução portuguesa.

5 Ver a passagem da primeira parte para a segunda, da Filosofia do Direito, op. cit.; na tradução portuguesa, a segunda parte tem o título "a moralidade subjetiva". 
Tomando como fio condutor da reconstrução do direito moderno a própria idéia defendida pela recém surgida camada burguesa, i. é., aquela da liberdade enquanto princípio organizador de todas as estruturas sociais da sociedade moderna, Hegel expõe, no capítulo sobre o direito abstrato, o instrumentário jurídico do qual os membros da sociedade deveriam fazer uso ao querer efetivar sua vontade pessoal, expressão de seus interesses particulares. Assim, o direito da posse, da propriedade privada e do contrato civil devem ser considerados como meios legais pelos quais os indivíduos impõem sua vontade particular ao mundo material e social; imposição esta que, segundo os argumentos implícitos de nosso filósofo, faz surgir um efeito importante: a liberdade dos individuos particulares revela-se como sendo condicionada pela limitação do campo de influência das figuras jurídicas a sua função de organizar o mútuo relacionamento entre as pessoas. Em outras palavras, as figuras jurídicas da posse, da propriedade privada e do contrato civil deveriam assegurar o livre exercício das vontades individuais sem, no entanto, poder interferir nas condições materiais deste relacionamento interpessoal. $\mathrm{O}$ direito do contrato civil, p. ex., regulamenta e garante, de fato, apenas o livre relacionamento dos contratantes, independentemente do objeto ou conteúdo material em relação ao qual os parceiros do contrato entram em acordo. Aliás, evidencia-se ai a condição necessária ou, melhor ainda, a condição da possibilidade de poder fechar contratos em cima de qualquer conteúdo material como, $\mathrm{p}$. ex., o trabalho humano, batatas ou antigüidades sem valor de uso. Tendo que me contentar com esta afirmação referente às figuras do direito abstrato em Hegel, quero apenas sublinhar que sua reconstrução nos mostra uma surpreendente qualidade do direito liberal, a saber, seu caráter abstraidor quanto ao lado qualitativo-material do mundo da racionalidade das coisas, posteriormente identificado como campo da economia. ${ }^{6}$ Mais ainda, torna-se evidente que o direito moderno só consegue cumprir seu compromisso de concretizar a idéia de liberdade como princípio universal da organização sociopolítica através de um simultâneo processo de abstração da base material de nosso relacionamento social fazendo deste processo a condição de possibilidade objetiva da realização da autoconsciência liberal. Parece-me ser esta uma das razões principais do fato de a sociedade capitalista conseguir negociar quase tudo, independentemente das qualidades ou da substância materiais em jogo; o direito não tem as condições de conter esta tendência que caracterizo como de omninegociabilidade se não quiser auto-suspender sua própria finalidade, i. é, a garantia da validade universal do princípio da liberdade pessoal.

Se a sociedade moderna contasse apenas com as figuras jurídicas citadas do direito abstrato, é óbvio que não disporia de critério nenhum de legitimação quanto à prevalência de um outro interesse particular, de uma ou outra imposição da livre vontade pessoal enquanto norma moral para todos. Pois, ao excluir o lado material-qualitativo do mundo da racionalidade das coisas como possivel critério de decisão, resta ao direito liberal somente uma exigência de comportamento, dirigida à consciência dos sujeitos do agir: cada um deveria levar em conta o respeito pela liberdade dos outros determinando seu agir por esta consciência. É exatamente este ponto crucial em que a questão da moralidade entra em cena buscando enraizar a idéia da liberdade

6 Segundo Hegel, a Economia Política é "uma das ciências que nos tempos modernos surgiram como em seu terreno próprio. Demonstra o seu desenvolvimento como o pensamento descobre, na infinita multiplicidade de minúcias que se the apresentam, os princípios simples da matéria" ("die einfachen Prinzipien der Sache, der in ihr wirksamen und sie regierenden Verstand herausfindet") § 189 FdD, nota. A tradução não consegue capturar o ponto central do argumento hegeliano! 
universal na auto-reflexão do sujeito enquanto sujeito moral, i.é, enquanto alguém que, pela sua atividade, deveria estar consciente de que seu agir deveria ser compatível com a liberdade de todos os outros ou, melhor ainda, propor-se a si mesmo a inclusão da idéia geral da liberdade em seu propósito. De tal maneira, a consciência moral representaria uma peça constitutiva do processo visado pelo direito liberal quanto à garantia da efetivação do princípio de liberdade para todos.

Pergunta-se, no entanto, como seria possível garantir a coincidência dos interesses particulares das pessoas com seu dever de respeitar a liberdade dos demais? Será possivel encontrar um mecanismo capaz de conciliar estes dois lados?

Ao falar do ponto de vista de um "direito da vontade moral", ${ }^{7}$ Hegel remete a uma saída deste impasse aparente, a fim de fazer valer a liberdade como princípio universal e, simultaneamente, conteúdo verdadeiro do agir individual das pessoas. Ora, em contrapartida, às figuras jurídicas do chamado direito abstrato, cuja aplicação casual e meramente relativa - por estabelecer somente obrigações entre as pessoas envolvidas - viria mesmo a facilitar o uso indevido ou arbitrário da liberdade - como, p. ex., no caso extremo do $\mathrm{crime}^{8}$ - o direito do agir moral impõe a exigência de as pessoas agirem com a consciência e o propósito de promoverem, através de suas ações, a efetivação da liberdade dos demais. Nas palavras de nosso filósofo: "A sua personalidade, enquanto tal a vontade apenas existe, no direito abstrato, passa agora a ser o seu objeto, e assim a subjetividade infinita para si da liberdade constitui o princípio do ponto de vista moral." ( $\S 104 \mathrm{FdD}) \mathrm{E}$, completando este raciocínio quanto à interna estrutura auto-reflexiva da vontade moral, Hegel segue, no § 107, da seguinte maneira: "A autodeterminação da vontade moral é também um momento de seu conceito e a subjetividade não é apenas o que ele tem de existência, senão é a sua determinação própria... Segundo este direito, a vontade só existe e reconhece algo na medida em que este é o seu, encontrando-se a vontade como subjetiva. (grifado por mim, H.G.F.)" Sem dúvida, o critério por Hegel introduzido enquanto característica do que deveríamos chamar a moralidade moderna, não passa de ser um critério bastante restritivo; qualificação esta à qual voltaremos mais tarde.

Para nossos fins, acho que uma primeira abordagem mais externa dos problemas da moralidade, no contexto do auto-entendimento da sociedade liberal, poderia facilitar a compreensão dos raciocínios posteriores. Falo da interpretação de uma expressão freqüentemente utilizada por Hegel, a saber, a formulação "o direito da vontade subjetiva" ou, como o § 114 repetirá, "o direito da vontade moral". Qual é o elemento tão curioso nestas expressões? Não causa sensação de estranheza a íntima ligação do Direito com a Moral, frente às nossas experiências sociais e políticas no dia-a-dia? Será que o Direito e a Moral não pertencem a contextos diferentes de fundamentação de seus principios?

Ora, mesmo sem conhecer ainda nada da fundamentação sofisticiada, dada por Hegel à relação complexa entre Direito e Moral, vale a pena apoiarmo-nos, inicialmente, numa experiência aparentemente superficial e portanto externa. Pedindo, p. ex., um direito legal em meu favor, não estou interessado em questões referentes à legitimidade moral do uso efetivo deste direito que a lei me dá. Pelo contrário, o direito positivo providencia normas calculáveis para nosso comportamento dispensando-nos da preocupação com a eventual imoralidade de nosso agir. Mais ainda, a qualificação do

7 Compare, p. ex., a formulação em $\S 114 \mathrm{FdD}$.

8 Ver os $\S \S 90$ a 103 FdD. 
agir enquanto imoral só encontraria uma base de critérios em contextos de reflexão juridicamente não qualificáveis. Se eu, enquanto proprietário legítimo de um amplo terreno, fizesse uso deste direito querendo expulsar, p. ex., familias sem-terra acampadas ilegalmente na minha fazenda, ninguém, nem o juiz responsável pelo caso, poderia me negar o pedido e, portanto, impedir a retirada das pessoas de minha propriedade. As familias atingidas ou, o que acontece freqüentemente, instituições sociais ou humanitárias, decepcionadas com minha insistência na legalidade, não disporiam de meio jurídico nenhum senão do apelo moral a fim de me levar a mudar de idéia. Neste caso, o apelo moral teria que buscar apoio em argumentos oriundos de uma reflexão qualitativa opondo, p. ex., ao meu direito particular de proprietário a vida e o bem-estar dos atingidos enquanto valores de maior importância que deveriam prevalecer em relação ao meu interesse particular. Porém, tal reflexão não poderia ser enquadrada nos princípios que regem o direito liberal ou, em outras palavras, a vontade moral do direito é outra em comparação com aquela que remete a valores substanciais. Em nossa sociedade parece ser evidente que o recurso a normas morais só faz sentido a partir do momento em que todos os recursos jurídicos tenham sido esgotados, inclusive o recurso ao direito da vontade moral.

Frente a tais experiências do dia-a-dia, o mundo da normatividade jurídica e aquele das convicções morais são vistas como duas esferas de normatividade nitidamente distintas, desvinculadas uma da outra. Mesmo assim, porém, Hegel insiste em falar do "direito da vontade moral" apontando, obviamente, uma interdependência surpreendente das duas esferas ao querer caracterizar o sistema do direito moderno e o processo de concretização do ideal liberal mediante a estruturação jurídica das relações sociais. Qual é o motivo deste raciocínio tão contrário a nossa experiência vivida? Conseguiria o direito moderno impor a idéia da liberdade universal só sob a condição de identificar as normas morais com aquelas jurídicas? Quais seriam as conseqüências de uma tal identificação? Finalmente, como poderia tal identificação ser legitimada? Encontraríamos aí a chave para a melhor compreensão da função essencial da moralidade na sociedade liberal-capitalista? Com estas perguntas tematiza-se 0 fundamento ideológico de nosso agir sob as determinações do liberalismo. Mesmo sem querer investir muito em análises pormenorizadas do texto hegeliano, pode-se esperar que a legitimação do agir moral gire em torno da necessária conciliação do interesse particular dos indivíduos com a pretensa universalidade do ideal da liberdade.

\section{2}

Uma passagem aparentemente periférica do texto hegeliano, a saber, a nota junto ao parágrafo $118 \mathrm{FdD}$, servir-nos-á como ponto de partida, a fim de entendermos melhor o enfoque do que Hegel chama "o direito da vontade moral", ou seja, a postura moral dentro dos princípios que regem a sociedade moderna. Em lugar inesperado, este texto trata de uma suposta diferença entre o agir moral do herói grego e, por outro lado, do homem moderno que vê suas atividades orientadas pelas regras de jogo do direito liberal. Ai, o raciocínio de Hegel parece-me revelar o verdadeiro espírito da moralidade vigente em nossos dias e entronisado há dois séculos. Cito o trecho decisivo deste texto: "A autoconsciência heróica (como nas tragédias antigas, Édipo, etc.) não se elevou ainđa de sua solidez à reflexão sobre a diferença entre feito e ação, entre os dados exteriores e o propósito consciente das circunstâncias, menos ainda à 
disposição das conseqüências aceitando, antes pelo contrário, a responsabilidade referente à proporção integral do feito". Ora, antes de destacar o sentido pleno e os critérios da contraposição do herói grego em relação ao sujeito moral do mundo moderno lembrarei, brevemente, a postura ético-moral, atribuída à figura do herói grego da tragédia comparando-a, a seguir, com a concepção da responsabilidade subjetiva segundo os ideais liberais. Escolhendo a figura de Édipo não quero apenas fazer jus ao texto de Hegel; mais ainda, acho que o mito em torno deste herói representa fonte inesgotável para caracterizar, de modo exemplar, a perda e o esvaziamento de critérios substanciais em busca da determinação da responsabilidade do homem enquanto sujeito moral, i. é, enquanto sujeito do direito liberal.

No mito de Édipo temos, ao início, pela frente um homem soberano que, enredado na estrutura sócio-política de sua pólis, vê-se dominado apenas pelo destino divino; destino este que, segundo a visão dos gregos, determina sua vida e, com esta, seu próprio agir social e político. Antecipando um pouco o caráter deste mito, quero destacá-lo como a primeira e uma das mais perfeitas peças policiais: o investigador do crime será levado, ao longo de seu trabalho intransigente, a um surpreendente resultado final segundo o qual ele mesmo descobre ser ele o criminoso que cometera 0 homicídio do próprio pai para casar, depois, com sua mãe. Sem trazer à tona o sentido mitológico dos referidos crimes, é suficiente reconstruir a encenação do drama para percebermos que não se entenderia nada da tragédia de nosso herói se não nos déssemos conta da relação tensa, surgida entre a perspectiva do agir individual de Édipo e as normas morais e políticas a serem instauradas na vida pública da pólis. Então, darei a seguir breve resumo do mito tentando sublinhar aqueles aspectos que servem para entender melhor a consideração hegeliana, acima citada.

Ainda criança, Édipo foi abandonado por seus verdadeiros pais, o casal real de Tebas em reação a uma sentença recebida pelo oráculo que previa exatamente os crimes mencionados. Querendo impedir a efetivação desta sentença, o casal real condicionava, sem sabê-lo, o primeiro elo da cadeia que levaria aos crimes. Pois, o pastor encarregado de abandonar a criança nas montanhas, a entrega a um colega que a leva para Corinto, a cidade rival de Tebas. Acolhido e adotado pelo casal real daquela cidade, a criança sobrevive seu enjeitamento original considerando-se ser filho legitimo dos pais adotivos. Adulto, Édipo toma conhecimento de seu destino previsto pelo oráculo; com medo de matar o pai e casar com a própria mãe, sai de Corinto a fim de ficar longe de seus pais. No meio do caminho de fuga e querendo passar, perto de um cruzamento, por uma carroça cujo condutor não quer ceder espaço, enfurece e acaba matando o outro sem poder saber, sob as circunstâncias dadas, que aquele foi seu verdadeiro pai, i. é, o rei de Tebas. Nas proximidades da cidade de Tebas, enfrenta a esfinge e ganha, como prêmio pela resolução do enigma que esta lhe tinha colocado, a rainha de Tebas por esposa. É claro que também neste segundo caso, Édipo não pode adivinhar que a rainha é, na verdade, sua própria mãe natural. Em reação aos sacrilégios cometidos, os deuses resolveram mandar uma praga veemente para a população sofrida de Tebas advertindo, através do oráculo, que esta só seria suspensa se o criminoso, morador de Tebas, fosse devidamente punido e expulso da cidade. Ao tomar conhecimento deste oráculo, o próprio Édipo encaminha detalhada investigação do caso; processo este que o leva a descobrir nos crimes os seus próprios feitos. A tragédia termina, como sabemos, com o auto-ofuscamento de Édipo e sua saída da cidade a fim de cumprir a punição prometida ao criminoso e liberar a cidade da praga. 
Ao usar o termo feito ao invés da palavra ação para caracterizar os crimes de nosso herói, Hegel marca a diferença decisiva entre a figura do herói grego e a postura do homem moderno. Pois, entende-se com o termo feito uma atividade humana cujas conseqüências objetivas não têm fundamento no propósito consciente, nèm na intenção subjetiva da pessoa. Já o termo atividade humana, no seu sentido preciso, deveria ser excluído da tentativa de descrever a situação, atribuindo-se a este termo a conotação do agir consciente que ultrapasse os limites de uma efetuação meramente objetiva. Vimos Édipo cometer os crimes sem o querer ou saber; mesmo assim, ele assumiu, com todo rigor, a resposabilidade ilimitada pelos efeitos de seus feitos no intuito de liberar a pólis da praga divina. E como se isto não bastasse, ele aceitou a punição por ele mesmo anunciada ao criminoso quando se iniciara a investigação.

Com tal atitude, deu prova não só da necessidade de assumir a responsabilidade integral quanto aos efeitos exteriores destes seus feitos mas, sobretudo, sua disposição moral de fazer prevalecer o bem público enquanto valor último do agir político. É esta sobreposição do bem público aos interesses do bem-estar particular que faz de Édipo o ideal do homem político - o zoón politikón - da pólis. Encontra-se aí a solução da tensão, acima indicada, em favor do bem da comunidade que levara nosso homem a sacrificar seus interesses individuais assumindo o que Hegel definiu como "responsabilidade na extensão plena de seu feito". A reflexão "sobre a diferença entre os feitos e a ação" está, sem dúvida, vinculada com a distinção dos principios morais, vigentes no mundo social da pólis e, por outro lado, na sociedade liberal de nossa época. Não há, na pólis, uma coincidência do interesse particular com o bem público, senão a submissão do primeiro ao último; solução esta que não se encontra mais na concepção liberal do direito moderno.

Contrapondo a figura de Édipo àquela do homem moderno, Hegel leva-nos ao centro da problemática da vontade moral e, com isso, à especificidade da concepção da moralidade hoje. Pois, do ponto de vista liberal, é claro que uma atitude como aquela de Édipo não escaparia ao qualificativo de ingênuo, senão ridículo e completamente inadequado à realidade social e aos principios nela reinantes. Mesmo que, por vezes, nos queiramos enganar esperando, p. ex., de nossos políticos que assumam um comportamento orientado pela idéia do bem público, sabemos no fundo que seria pouco realista querer encontrar alguém disposto a sacrificar-se pessoalmente em favor de tal princípio. Na melhor das hipóteses ocorreria a coincidência dos interesses particulares com aqueles do bem público via acaso, ou seja, sem ser intencionalmente procurada. Perguntamo-nos, por isso, quanto aos motivos que levam hoje à pouca valorização do bem comum enquanto princípio fundamentador do agir. Para obter uma resposta, teremos que voltar, mais uma vez, ao sentido do falar do "direito da vontade moral".

Através da formulação "direito da vontade moral", Hegel insiste, obviamente, em introduzir um critério delimitador quanto às possíveis exigências que hoje podem ser feitas no que tange à substância do agir moral, no contexto da visão liberal. Mais ainda, a formulação sugere a expectativa de o próprio direito liberal providenciar, em última instância, os limites essenciais da conotação a ser atribuída à vontade moral. A expressão "direito da vontade moral" remeteria, pois, à diagnose segundo qual a época moderna ter elaborado um critério da moralidade sem qualquer referência a instân- 
cias de legitimação fora do Direito. Em outras palavras, a moralidade deveria encontrar na própria lógica do direito liberal seu princípio de orientação.

Em conseqüência desta observação pode-se já prever a necessária dependência da definição da moralidade do contexto jurídico-legal. Assim, a expressão "direito da vontade moral" visa identificar a responsabilidade subjetiva com o alcance objetivo do Direito, isto é, com o campo do agir humano estruturado pelo próprio Direito.

Já conhecemos, antes, o restrito campo de manobras que limita, por sua vez, a força estruturadora do Direito: a organização das relações interpessoais pelo direito liberal só é possível à base da simultânea abstração desta força estruturadora de todos os problemas ligados com a mediação material-econômica da vida social. Tal abstração deveria afetar, também, o alcance e os limites da responsabilidade moral do agir humano, sob pena de o sistema do direito liberal tornar-se incoerente e contraditório. Quanto a este raciocinio, Hegel dá-nos alguns indícios já anteriormente mencionados; repito a passagem citada: "Daqui se conclui que o ponto de vista moral assumirá a forma do direito da vontade subjetiva. Segundo este direito, a vontade só reconhece o que é seu e só existe, na medida em que este é o seu, encontrando-se neste como algo subjetivo." ( $(107 \mathrm{FdD}$ ). Falando em termos técnicos da linguagem jurídica, posso lembrar a validade destes mesmos critérios na definição dos tipos legais do Código Penal: a responsabilidade pelas conseqüências do agir limita-se àquele conteúdo compreendido pela vontade e pelo propósito subjetivos do culpado, ficando qualquer efeito objetivo, por ele não previsivel ou intencionado, fora do julgamento legal. Como se vê, o direito liberal dá ao homem os meios argumentativos para restringir suas obrigações ou seus deveres legais e, com isto, sua responsabilidade ao conteúdo incluído no seu querer. Deste modo, podemos falar do "direito da vontade moral" enquanto mecanismo legal que legitima as pessoas a desresponsabilizarem-se de efeitos objetivos de sua atividade na medida em que estes não sejam alvo de seu querer. Ora, quem assumisse responsabilidade irrestrita, ou seja, excedente de seu querer subjetivo - tal como o herói grego - enfrentaria, sem dúvida, o escárnio de seus contemporâneos por não recorrer à justificativa legal. Evidencia-se aí o pleno sentido da diferença introduzida por Hegel, entre o feito e a ação, entre "os dados exteriores e o propósito consciente das circunstâncias" do agir; diferença esta que, em última instância, demonstra os limites da responsabilidade moral dentro da visão moderna de nosso direito.

Ao funcionar como sistema de desresponsabilização em relação àquelas conseqüências do agir que excedem o alcance marcado pelo propósito ou descuido subjetivos, o Direito parece reforçar ou mesmo ampliar a tensão entre os interesses subjetivos e a idéia do bem comum, i. é, entre o nivel do egoísmo particular e aquele do ideal político. Como o sistema do direito liberal consegue conciliar estas duas perspectivas opostas sem, no entanto, suspender uma delas? Qual seria o princípio de conciliação capaz de salvaguardar o direito de liberdade tanto para o indivíduo, quanto para os demais? Com tais perguntas chegamos à terceira observação de peso na tentativa de compreendermos melhor o papel atribuído por Hegel à moralidade na tradição do pensamento liberal.

A tensão extrema entre os dois níveis acima expostos só não desembocaria na implosão e dissolução da sociedade burguesa se fosse possível cumprir pelo menos duas condições, a saber, respeitar os diferentes interesses materiais das pessoas e conciliá-los através de sua transformação em estruturas legalmente justificadas. A solução dada por Hegel a esta tarefa difícil é tão simples quanto surpreendente. Ela se 
dá através da restrição mútua do conteúdo dos deveres e direitos legais de cada pessoa quando negligencia a questão da legitimidade dos interesses materiais. Assim, os deveres não ultrapassam o conteúdo do agir determinado pelas obrigações legais, ou seja, a condição suficiente do cumprimento dos deveres está no respeito das formas legais do agir. Em outras palavras, trata-se de um princípio puramente quantitativo de restrição mútua dos deveres e direitos. As exigências referentes ao agir subjetivo - i. é, o agir segundo o direito da moralidade - não podem ser maiores do que o respeito pelos direitos que organizam o relacionamento social como um todo. É óbvio, portanto, que os deveres não atingem, deste modo, as decisões sobre o conteúdo material e sua força organizadora que influenciam diretamente na postura de cada indivíduo. A restrição mútua entre deveres e direitos só pode funcionar se o direito liberal deixar fora de consideração a avaliação dos interesses materiais e os valores substânciais que determinam, ao nivel sócio-econômico, o comportamento social. Cito a passagem central do parágrafo $155 \mathrm{FdD}$ que indica o critério encontrado por Hegel: "Nesta identidade da vontade universal e da particular, coincidem o dever e o direito e, no plano da eticidade, tem o homem deveres na medida em que tem direitos e direitos na medida em que tem deveres." (grifado por mim, H.G.F.) O perigo do confronto direto entre os interesses subjetivos vê-se conjurado pela imposição de uma medida meramente quantitativa, ou seja, pela delimitação forçada do conteúdo do agir subjetivo por aquele espaço do livre agir que é garantido pelas disposições legais do agir social. Quem se der conta desta condição vai agir dentro do padrão moral, fixado pelo direito da moralidade. Em última instância, o principio da legalidade do agir subjetivo tornase, assim, o critério da moralidade objetiva, exigindo-se do sujeito moral apenas o respeito pelos meios legais em vigor sem questionar seu essencial conteúdo materialqualitativo.

A função deste princípio é simples, porém ambígua: aos respeitarmos os espaços legais de nosso agir, instrumentalizando as disposições do Direito em favor de nossos interesses, satisfariamos necessariamente todas as possiveis exigências legítimas que a sociedade civil poderia nos impor ou o Estado cobrar de nós. Movimentando-nos, de tal maneira, dentro dos limites legais, não teríamos motivos para nos preocupar com os efeitos de nosso agir eventualmente danosos para os demais parceiros; pois, o cumprimento das formas da legalidade já nos dá as condições de desresponsabilizarnos de tudo que, de um ponto de vista de valores e principios substanciais, poderia ter conotação de imoralidade.

Diagnostica-se, portanto, a partir daí que a possibilidade de hoje falarmos do "direito da vontade moral" depende necessariamente da recusa de uma fundamentação da moralidade fora do ideal liberal, i. é, fora dos critérios impostos pela lógica do direito moderno. Mais uma vez, apreendemos através da própria filosofia hegeliana que a idéia da moralidade na época do liberalismo não precisa mais legitimar sua razão de ser em convicções material ou metafisicamente fundadas. Ela a legitima apenas a partir de uma instância a que dou o nome de princípio de mera legalidade da moral. Ora, a idéia da moralidade segundo o pensamento e a autoconsciência burguesas não resulta mais da luta entre ideais universal-normativos; muito pelo contrário, é a organização legal do terreno do agir social que a determina dando, assim, ao indivíduo as disposições de efetivar seus interesses, até mesmo no âmbito do domínio de convicções contrariadas. Quem não quiser renunciar à discussão de tais ideais da fundamentação moral, deverá buscar contextos além da racionalidade do direito liberal como, p. ex., princípios teológicos, místicos ou metafísicos. 
Ao avesso desta lógica implacável do "direito da vontade moral" abre-se um abismo ou, o que é o mesmo, um vazio quanto à legitimação essencial do agir. A negligência de valores supremos, capazes de darem orientação a conteúdo e finalidade do agir, leva a sociedade liberal a necessariamente conviver ou, antes, até sobreviver com o que poderíamos chamar a sua moralidade equívoca. Como já insinuado pelo exemplo, há pouco mencionado, do fazendeiro e as famílias sem-terra, poderíamos estender este problema da abstração do direito liberal em relação aos conteúdos materiais subjacentes, à concepção da própria moralidade liberal: quem respeitar a validade das disposições jurídicas enquanto quadro instrumental de seu agir, movimentarse-á dentro de seus deveres cumprindo, desta maneira, as condições suficientes, exigidas pelo "direito da vontade moral". Qualquer objeção que visa efeitos objetivos desgradáveis ou até danosos para os demais contemporâneos, resultantes do agir legal, ultrapassaria o campo do julgamento moral-legal; situação esta que vale mesmo no caso de conseqüências aparentemente injustas de um ponto de vista da justiça social. Tais objeções teriam que recorrer a outros critérios para a fundamentação da moralidade: ao se posicionar fora do alcance da racionalidade do direito liberal, tais critérios não poderiam ser juridicamente cobrados. Em conseqüência disto, seria também impossível atribuir a responsabilidade pessoal ao indivíduo agente dentro dos termos exigidos pelo "direito da moralidade" liberal. Dentro deste horizonte, o empresário ágil que explorasse ao máximo a força de trabalho de seus empregados, poderia tranqüilamente recusar qualquer responsabilidade subjetiva pelos efeitos contraditórios aos quais esta atitude conduzisse, i. é, o seu próprio enriquecimento e o empobrecimento paralelo de seus mal pagos trabalhadores; estes últimos, por sua vez, nem poderiam se queixar desta situação, pois eles teriam a mesma chance legal de chegar à posição confortável de seu patrão fazendo uso dos meios legais-jurídicos. Tais efeitos materialmente opostos são apenas resultados da instrumentalização das disposições legais como, no caso citado, do direito de contrato civil e do direito de trabalho.

A verdadeira raiz deste efeito chamado a dupla moralidade da sociedade liberal encontra-se, portanto, na força abstraidora do sistema do direito moderno, sistema este que, ao querer efetivar a liberdade de todos, só consegue cumprir este propósito sob a condição de não interferir na constituição material das relações sociais. Em termos da crítica da Economia Politica poder-se-ia dizer, também, que o direito liberal devido à lógica de seu próprio principio fundamentador - não consegue abranger aquelas atividades humanas, deformadas por um processo econômico de coisificação dando, assim, o espaço necessário para que a economia capitalista possa desdobrarse sem restrições impostas pelo próprio Direito. O Direito representa, em última instância, a racionalidade da formação social da comunidade moderna enquanto a economia capitalista passa a organizar a racionalidade das relações materiais, i. é, "a racionalidade das coisas" (G. W. F. Hegel). Reconhecemos aí o motivo da diagnose de Max Weber, inicialmente citada, quanto ao convívio complementar do sistema do direito liberal com a economia do capitalismo.

Para concluir meus raciocínios, quero apenas acrescentar um raciocinio em torno de uma questão muito discutida, ou seja, em torno da possível fundamentação de uma ética ambiental. Tal abordagem dar-me-á, também, a oportunidade de mostrar um pouco da capacidade diagnosticadora de minhas interpretações anteriormente expostas. 
Como se sabe, até os anos setenta, o ar, o solo e a água foram considerados bens públicos, livremente disponiveis para quem tinha a intenção de utilizá-los. Enquanto recursos naturais, sua exploração econômica ou social obedecia apenas aos critérios referentes ao seu valor de uso, ou seja, determinados pelo interesse em usufruir sua qualidade específica a fim de cumprir as mais variadas necessidades. $\mathrm{Na}$ medida em que a utilização destes bens naturais resultara, cada vez mais, na sua danificação ou, em muitos casos, na destruição praticamente irreversível, iniciou-se um processo de reconsideração quanto aos princípios de seu tratamento, no intuito de recuperar tais fontes escassas, essenciais para a sobrevivência e reprodução da sociedade. Reconhecida a substância qualitativa do Meio Ambiente e de seus recursos, restava agora procurar, com ansiedade crescente, principios capazes de inverter a tendência destruidora do Meio Ambiente, mais especificamente de seus recursos.

No que tange aos bens naturais, tradicionalmente considerados livres, o grande passo virtualmente salvador deu-se pela decisão de internalisar os custos de sua recuperação e disponibilidade como fator do cálculo econômico, já que a economia capitalista baseia-se no princípio da escassez dos bens de produção. Desde então, os referidos bens vêm sendo enquadrados no domínio da racionalidade deste sistema econômico fazendo nascer, ao mesmo tempo, a nova disciplina chamada Economia do Meio Ambiente ou Economia Ambiental. Pergunta-se, no entanto, o que aconteceu verdadeiramente com tal inclusão dos bens ambientais públicos na lógica da economia atual. Ao meu ver, tal subsunção ajuda-nos, de fato, a explicar alguns impasses aos quais a discussão sobre o Meio Ambiente chegou nos últimos tempos. Querendo lembrar apenas dois limito-me a problematizar aqueles que têm a ver com uma ética do Meio Ambiente.

Em primeiro lugar, quero mencionar a transformação sofrida pelos bens naturais. É óbvio que tais bens originalmente encarados sob o ponto de vista de suas qualidades de uso, tornaram-se componentes calculáveis de modo meramente quantitativo da produção, ou seja, transformaram-se em unidades quantitativas, capazes de serem medidas e comparadas com qualquer outro elemento do balanço econômico. Deixouse, assim, de utilizar critérios morais de avaliação para decidir os vários conflitos de uso em relação ao mesmo bem. Qualquer raciocínio qualitativamente determinado, orientador do comportamento frente aos bens da Natureza não tem mais espaço dentro da racionalidade econômica. Perdidos os vínculos com as necessidades do homem e suas condições de vida, os bens da Natureza passam a assumir a qualidade de mercadorias quaisquer. Constata-se, portanto, que, em vez de encaminhar um processo de verdadeira salvação dos recursos ambientais, sua internalização tão festejada na lógica da produção capitalista fez desaparecer até a última possibilidade de decidir conflitos de seu uso à base de argumentos e conviç̧ões fundados em valores e qualidades últimos.

A partir daí e chegando à minha segunda observação, parece-me natural o impasse a que chegou hoje o discurso entre representantes dos movimentos ecológicos e aqueles da Economia reinante. Os parceiros recorrem, na verdade, a horizontes de legitimação mutuamente incompativeis, quando a perspectiva ecológica argumenta à base de principios aos apelos morais, fundados em uma hierarquia de valores, ao mesmo tempo em que o economista recusa tais reflexões insistindo na legalidade de sua atitude e na racionalidade do mercado. Enquanto ambos não chegarem a conscientizar este problema, não haverá saída do impasse. Pois, é na indicada tensão entre 
a legitimação material e a forma legal de nosso trato dos recursos ambientais que se define, em última instância, a concepção liberal da ética do Meio Ambiente.

Sem dúvida, a argumentação encontrada ou, melhor ainda, extraída da Filosofia do Direito de Hegel revela-nos o preço a ser pago pela efetivação do ideal liberal na sociedade moderna; preço este que afeta, de modo direto, também a concepção da moralidade daí definida. Por um lado, vemos a sociedade contentar-se com uma visão que, sob dadas formas legais, não exige a reflexão sobre valores últimos ou princípios substanciais do agir humano; por outro, sabe-se que sem tais orientações correriamos sérios riscos quanto ao nosso futuro sócio-político. Isto significa, primeiro, que as convicções tradicionais da moralidade sofreram transformação profunda no sentido do esvaziamento de seu conteúdo; em segundo lugar, conclui-se dai que as grandes conquistas históricas, efetivadas em nome do ideal do liberalismo, arrastaram consigo, em seu avesso, um processo de potencial altamente destrutivo ou, pelo menos, um processo contraditório. Pois, na medida em que o critério da legalidade prevalece, sentimos falta de orientação por conteúdos legítimos; no caso contrário, ou seja, da prevalência de conviç̧ões substanciais em comparação com o principio da legalidade do agir moral, minaríamos inevitavelmente a validade do ideal liberal. Uma reversão deste desenvolvimento, i. é, a possivel suspensão deste beco sem saída só será viável a partir de uma clara tomada de consciência que nos obrigue a colocar em cheque a racionalidade do próprio liberalismo. 